\title{
Articles
}

The Person and the Challenges

Volume 2 (2012) Number 2, p. 9-28

Henryk Szmulewicz

The Pontifical University of John Paul II in Cracow, Poland

\section{Love and Truth in Social Involvement of the Church}

\section{Abstract}

This study begins with a brief outline of the essence of the whole encyclical Caritas in veritate. Benedict XVI expresses the desire for „the dialogue with the world". He understands this dialogue as a special kind of the service of the Church towards eternal love and truth, fully revealed in Christ. The dialogue of the Church with the world, in the spirit of love and truth, is accomplished every day at the level of so-called official relations. There are numerous opinions that in the past the Church repeatedly neglected the dialogue with the world. Indeed, the Church historians point out the existence of examples of the fall of the authority of the Holy See in particular countries and circumstances. Similarly, the Church is the sign of objection in the contemporary world. Instructed by past experiences the Church is aware that what is necessary for the renewal of culture and society, is evangelical love and truth.

\section{Keywords}

Authority, culture, dialogue, Kingdom of God, love, social doctrine of the Church, society, truth.

„The complexity and gravity of the present economic situation rightly cause us concern but we must adopt a realistic attitude as we take up with confidence and 
hope the new responsibilities to which we are called by the prospect of a world in need of profound cultural renewal, a world that needs to rediscover fundamental values on which to build a better future". Not only these words, however, the essence of the whole encyclical Caritas in veritate constitute the confirmation of the social dimension of the Church mission. Benedict XVI expresses the desire for ,the dialogue with the world", understanding this dialogue as a special kind of the service of the Church towards eternal love and truth, fully revealed in Christ.

The dialogue of the Church with the world, in the spirit of love and truth, is accomplished every day at the level of so-called official relations. The Holy See addresses - in its documents and during the numerous meetings - diplomatic representatives not only as exponents of the governments, systems and political structures but also as representatives of the nations that within these structures express their sovereign existence, their political independence and capacity for self-authoring. „The world” and its various structures are perceived by the Church as cultural and religious diversity, which was indicated by John Paul II, with its own authorities present in it $^{2}$.

There are numerous opinions that in the past the Church repeatedly neglected the dialogue with the world ${ }^{3}$. Indeed, the Church historians point out the existence of examples of ,the fall of the authority of the Holy See” in particular countries and circumstances $^{4}$. Simultaneously, one cannot forget that the history of the Church brings numerous examples which prove ,the prestige and authority of the popes"s.

${ }^{1}$ Benedict XVI, the encyclical Caritas in veritate (29 June 2009), no. 21.

${ }^{2}$,With the authority she received from her Lord, the Church repeats to today's Europe: Europe of the third millennium, ,let not your hands grow weak!" (Zep 3:16); do not give in to discouragement, do not resign yourself to ways of thinking and living that have no future because they are not based on the sound certainty of God's Word!". John Paul II, Apostolic Exhortation Ecclesia in Europa (dated 28 June 2003), no. 120.

${ }^{3}$ Among others, W. Hryniewicz, Dlaczego głoszę nadzieję?, Warszawa 2004, p. 38, wrote about these viewpoints.

${ }^{4}$ Cf. B. Kumor, Historia Kościoła, volume 4, Jesień kościelnego średniowiecza, Lublin 2001, p. 26.

${ }^{5}$ H. Fros, Pamiętając o mieszkańcach nieba. Kult świętych $w$ dziejach $i$ w liturgii, Tarnów 1994, p. 131. As a shining example we can indicate the pontificate of the Servant of God, John Paul II who as a man full of universal love. Directed by universal love, he supported efforts of many people and organizations - also extra-ecclesiastical ones. Cf. K. Bukowski, Odnowa i jedność, „Katecheta” 5 (1978), p. 230. In this aspect he appeared to be ,a straightforward witness of hope for the Church and the world who (was) received by the mighty of this world (...) as ,the greatest moral authority on earth". M. Cisło, Synodalne przesłanie nadziei. Ogólnokościelny Synod Biskupów 2001, in: ed. by J. Nagórny, M. Pokrywka, Nadzieja chrześcijańska a nadzieje ludzkie, Lublin 2003, p. 26. He was also regarded to be ,the authoritarian spokesman of anthropology and Christian ethics", S. Kowalczyk, Liberalizm i jego filozofia, Katowice 1995, p. 175. 
To analyze the issue of the Church relations towards the matters of "this world" in a proper perspective it is necessary to remember that the Church, directed by the spirit of evangelical truth and love, must - sometimes contrary to the world voice ,a pessimistic vision of the world in which the following dominate: conceit, unruliness, boastfulness of the scholars, contempt for holiness, attacks for the Holy See, and even divine authority of the Church"6. That is why, contrary to the presently disseminated opinions, only as being faithful to the Gospel, the Church will be perceived in the categories of ,international and moral authority"7.

However, the contemporary discussion about the Church and its reference to the world does not constitute a direct object of the analyses included in the encyclical Caritas in veritate, its essence confirms a special need for the proper understanding and interpretation of the Church social studies. This study embraces this need and reminds about a few theological principles on which the authority of the Church is based in the matter of renewal of the culture and society on the foundation of love and truth.

\section{The Fullness of the Revelation of Love and Truth in Christ}

Without love and truth the renewal of contemporary culture and society is not possible. This is the Church conviction which is based on the fundamental principle of its involvement in the social life: in Jesus Christ the fullness of the revelation of the way of the man and mankind to salvation has been accomplished. Now that in the centre of the evangelical message there are love and truth, the Church can and should express opinions and act for the benefit of renewal of culture and society on the foundation of these two closely related values: „Charity in truth, to which Jesus Christ bore witness by his earthly life and especially by his death and resurrection, is the principal driving force behind the authentic development of every person and of all humanity"s.

Jesus Christ constitutes the fullness of love and truth. Revealing impact and teaching word of God is highlighted in a particular way in Jesus Christ. From the standpoint of the social doctrine of the Church it is undeniable that divine revelation from the times before Christ was His announcement and preparation.

${ }^{6}$ N. Banaszak, Historia Kościoła katolickiego, volume 3: Czasy nowożytne 1758-1914, Warszawa 1991, p. 89.

${ }^{7}$ S. Witek, Etos chrześcijański - II. Przejawy, in: R. Łukaszyk, L. Bieńkowski, J. Gryglewicz (Eds.), Encyklopedia katolicka, volume 4. Lublin 1983, p. 1202-1212.

${ }^{8}$ Benedict XVI, the encyclical Caritas in veritate (29 June 2009), no. 1. 
That is why the Church reality in which revelation is depicted constitutes the way of the mankind to meet God's Son'.

Over the centuries christology and soteriology were virtually identified. Also, in the social doctrine of the Church and reflection of theologists soteriological viewpoint for the social dimension of the fullness of the revelation in Jesus Christ is dominant. Needless to say, there is no mistake or abuse in it as it is the accent enabling to notice the close connection between all the events from the life of Jesus and what constitutes the essence of the human history. Only in the soteriological key it is possible to understand the sense of addressing Jesus Christ as the Head of mankind.

The Old and the New Testament represent the record of the truth about great God's love. This love desires good for creation, prepares its self-revelation in it, it is clearly demonstrated in directing the history of salvation to Christ. Indeed, God loves His creation with dignity whose evidence is taking a human nature ${ }^{10}$. This is a glamorous proof that God is Love.

„In the beginning was the Word, and the Word was with God, and the Word was God (John 1:1) and thanks to this Word „we beheld His glory” (John 1:14). The fragment from the Prologue of the Gospel of St. John shows Christ as God's Revelator ${ }^{11}$. Here, St. John the Evangelist used the old testamental image of „,word” embedded in the wisdom literature. It gives meaning to the history of salvation, it is a carrier of the mysteries of God, it encourages people to live by faith as well as it performs God's commands (cf. The Book of Psalms 119:89; 174:15; 107:20; The Book of Isaiah 55:11; The Book of Proverbs 18:14). It is personified parallelly to personification of the Wisdom and Spirit of God.

In the Old Testament Logos becomes an ultimate self-revealing Word of God through which all the things were made, ,and without Him nothing was made that was made (John 1:3). After Him there cannot come a prophet who would be able to bring something new in God's revelation as well as nothing new and better can occur in place of what has been so far ${ }^{12}$.

"And the Word became flesh and dwelt among us" (John 1:14). The sign of this event is a figure of Mary, chosen for the Mother of the Incarnate Son of God. She gave her heart fully to God's love. Mary is the first person in whom the new awareness of the sense of God's love is manifested. At the Annunciation she asks the Angel: „How can this be since I do not know a man?” (Luke 1:34). She was

\footnotetext{
${ }^{9}$ Cf. E. Kopeć, Teologia fundamentalna, Lublin 1976, p. 62.

${ }^{10}$ Cf. R. Guardini, O Bogu żywym, Warszawa 1987, p. 123.

${ }^{11}$ Cf. W. Tatarkiewicz, Historia filozofii, volume 1, Warszawa 1993, p. 161-165.

${ }^{12}$ Cf. K. Rahner, Wierzę w Jezusa Chrystusa, Paris 1977, p. 50.
} 
„betrothed to a man whose name was Joseph” (Luke 1:27). Faithful to the promise, she remained a virgin, and the maternity which was accomplished in Her „came entirely from 'the power of the Highest', was a result of the Holy Spirit's coming upon her (Cf. Luke 1:35). Consequently, this divine maternity was a completely unpredictable answer for the human anticipation of the Israeli woman: it came to Mary as a gift of the God himself. This gift became a beginning and prototype of a new expectation of all people to match the eternal Covenant and a new and ultimate promise of God: the sign of eschatological hope"13.

God in Jesus Christ took the human nature to become accessible for the man and through his acts and words be able to reveal Himself - God of the triune love who died for salvation of the mankind. „No one knows the Son except the father. Nor does anyone know the father except the Son, the one to whom the Son wills to reveal Him" (Matthew 11:27; Cf. Luke 10:22). The Son is the One who knows the Father (Cf. Hebrews 1:2). The Christ revealing the Father emphasizes the communion of love that exists between Him and the Father. He presents this as an example: „That they all may be one, as You, Father are in Me, and I in You” (John $17: 21)^{14}$.

Jesus reveals God as a merciful father who rejoices at finding a lost sheep (Cf. Luke 15: 4-6), conversion of a single sinner who „was dead, and is alive again; and was lost and is found" (Luke 15:32). In view of the teaching of the Christ the revealed Father is not a master, a tyrant who oppresses, humiliates and punishes, yet, he is a good, merciful and providential father who even gives the man the freedom of withdrawing from Him and dissipating the legacy ${ }^{15}$. Merciful God's love finds its culmination in sacrificing His Begotten Son for the sins of the whole world. Paschal events bring the memory of the promise from the Protoevangelium where God announces saving the woman's progeny from slavery of the sin, death and the devil, using the words while addressing the snake: „He shall bruise your head" (Genesis 3:15). Therefore, God does not leave the man on his or her own but he demonstrates a saving initiative. To fulfill the promise, he does not even save His Son but he sends Him to die for us (Cf. Genesis 8:32). Redemption made by Jesus Christ brought the abundance of forgiveness and saving grace for the mankind.

\footnotetext{
${ }^{13}$ John Paul II, the Apostolic Letter Mulieris dignitatem on the occasion of the Marian year about dignity and vocation of a woman (15 August 1988), in: John Paul II, Wybór Listów Ojca Świętego Jana Pawła II, volume 1, Kraków 1997, no. 20.

${ }^{14}$ Cf. John Paul II, Wierzę w Jezusa Chrystusa Odkupiciela, Warszawa 1991, p. 75.

${ }^{15} \mathrm{Cf}$. Jezus Chrystus, jedyny Zbawiciel świata, wczoraj, dziś i na wieki. Oficjalny dokument Papieskiego Komitetu Obchodów Wielkiego Jubileuszu Roku 2000, Katowice 1997, p. 27.
} 
The fullness of the revelation of love and truth in Christ also constitutes the revelation of the Holy Spirit who comes from the Father and the Son, is the Spirit of Jesus and he accompanies His mission from the very conception. Before starting His public activity, Jesus receives the Holy Spirit and he is anointed by Him at the river of Jordan (Cf. Matthew 3:13-17) ${ }^{16}$, which has a messianic dimension. Jesus is a Messiah, God's Anointed. „Anointing” with its origins dates back to the Old Testament; it is about marking God's chosen people. Jesus, being the Son of God and God's Chosen One, was anointed with the Holy Spirit and power (cf. Acts 10:37) and since that moment he undertook the mission of public activity, which was completed with death on the cross, and ultimately - with glorious resurrection. Not only does Jesus receives the Holy Spirit but He also becomes an Intermediary in the process of giving the Holy Spirit to all the people ${ }^{17}$. This is the Holy Spirit who will remind the disciples all the saving events and will lead them to the whole truth in love (cf. John 14:26; 16:13).

The Son of God, descending from heaven to earth, does not look for His will but the will of the One who has sent him (cf. John 5:30; 6:38). For Him the food is to obey the will of God and at the same time finish His work (cf. John 4:34). The desire to obey the saving will of the Father inspires the life of Jesus and it is a motive of His activity ${ }^{18}$. That is why in the garden of Gethsemane He falls down to His knees and prays: „Father, if it is Your will, take this cup away from Me; nevertheless not My will, but Yours, be done!" (Luke 22:42). Also, on the cross in the act of obedience He says these words: „Father, in Your hands I commit my spirit" (Luke 23:46). The redemptive sense of obedience of Jesus is to some extent illuminated by His resurrection. He opened the gates of New Jerusalem ascending to heaven and sending the Holy Spirit. In this way the act of the perfect revelation of love and truth was completed - from God the Father through Jesus Christ in the Holy Spirit.

\section{Truth and Love Inscribed in the Social Doctrine and Activity of the Church}

The responsibility of the authentic interpretation of God's word in what is related to the renewal of culture and society was entrusted to the live Magisterium

\footnotetext{
${ }^{16}$ Cf. Y. Congar, Wierzę w Ducha Świętego, volume 1, Warszawa 1997, p. 52.

${ }^{17}$ Cf. John Paul II, Wierze w Jezusa Chrystusa Pana i Ożywiciela, Libreria Vaticana - Citta del Vaticano 1992, p. 174.

${ }^{18}$ Cf. CCC 607.
} 
in the name of Jesus Christ ${ }^{19}$. The social doctrine of the Church concerns the aspect of faith and customs, and it is mainly included in the statements of the popes and councils ${ }^{20}$. Recognizing the Church as ,the voice of God" directed to all the people in social issues is therefore impossible without believing in the presence of God's authority in the salvatory mission of the Church ${ }^{21}$. And this is the presence of God who saves through love 22 .

Those who addressed the Church hostilely throughout the ages tried to direct it onto the way of pluralism of the truth, which means multitude of truths concerning the same subject. There was and there is still this desire which „promotes recognition of a personal opinion for more credible than the one expressed by the Church. However, the very core of Christianity consists in obedience of faith (oboedientia fidei), that is obeying God by a man. This means

${ }^{19}$ „For it must not be forgotten that the Church has the right and the duty not only to safeguard the principles of ethics and religion, but also to intervene authoritatively with Her children in the temporal sphere, when there is a question of judging the application of those principles to concrete cases". John XXIII, the encyclical Pacem in terris (11 April 1963), no. 160.

${ }^{20}$ „The Church has the right and obligation not merely to guard ethical and religious principles, but also to declare its authoritative judgment in the matter of putting these principles into practice". John XXIII, the encyclical Mater et Magistra (15 May 1961), no. 239. Bishops headed by the Pope constitute the Magisterium. It has the right and obligation of authoritative teaching of the truth revealed in faithful obedience to the God's Word, in the light of the live Tradition of the Church and the sense of concern about the proper interpretation of the signs of the times. The mission of this Office ,is connected with the ultimate character of the covenant concluded by God in Christ with His people; the Magisterium is obliged to protect them from misrepresentations and weaknesses as well as provide them with objective possibility of believing without the mistake of the authentic faith". Potrzeba i zadania nowej ewangelizacji na przetomie II I II tysiaclecia chrześcijaństwa, in: II Polski Synod Plenarny (1991-1999), Pallotinum 2001, no. 8.

${ }^{21}$ „At the same time the conscience of each person should avoid confining itself to individualistic considerations in its moral judgments of the person's own acts. As far as possible conscience should take account of the good of all, as expressed in the moral law, natural and revealed, and consequently in the law of the Church and in the authoritative teaching of the Magisterium on moral questions. Personal conscience and reason should not be set in opposition to the moral law or the Magisterium of the Church". CCC 2039.

22 „This Magisterium can be held with a lower or higher frequency and take various forms, depending on time requirements, specific situations, possibilities and means which are at disposal as well as methods and techniques of broadcast. Taking into consideration the fact that at their bases there is a clear or implicit intention of adopting the opinion in the issues of faith and ethics they are related to the mission received by Peter and they take pride in authority which was given by Christ". John Paul II, Misja nauczania Następcy św. Piotra, in: John Paul II, Wierzę w Kościót - jeden, święty, powszechny i apostolski, Libreria Editrice Vaticana 1996, no. 3.

„Let them bear in mind above all that in the rules and laws promulgated by the Church there is question of doctrine regarding faith and morals; and that in the immense matter contained in the Sacred Books - legislative, historical, sapiential and prophetical - there are but few texts whose sense has been defined by the authority of the Church". Pius XII, the encyclical Divino afflante Spiritu (1943), in: BF III, no. 68. 
that God Himself determines faith (...) and the Magisterium interprets given revelation in the name of God"23.

Those who do not recognize the competences of the Church in the matters of faith and morals turn down the evangelical concept of the relationship between love and truth ${ }^{24}$ One of the reasons for rejecting authority of the Church is not taking into account its voice as an authentic interpreter of the biblical texts. And, after all, the Bible ,does not interpret itself, yet, it calls for an authentic interpreter. For the Catholics this is a community of believers, the Church led by the Holy Spirit through its leaders. This is not a matter of one's caprice. (...) The believer who makes his or her own interpretation of a particular fragment of the Bible (...), sooner or later accepts an authority that will remain undefined, this will be an accidental preacher or an author, group of co-believers or personal preferences. If the authority that we recognize has not been defined we have been under an illusion that act on our own behalf and independent of any outside standard whatsoever. In consequence, we actually succumb to, in turns, one undefined authority and then another" 25 .

Contrary to negative opinions about the Church disseminated in, for example, numerous mass media, in the matters of faith and morals, the Magisterium does not want - and also cannot - deprive a man of his right to the freedom of conscience. In the life of the Church there is always a binding obligation to show respect towards a man's conviction of the conscience as „humbleness and respect towards another person constitute the best assumption for a fruitful dialogue in which the conscience gains more and more light. Nowadays the authority in the Church sees more and more clearly how strongly human dignity calls for respect of the freedom of conscience ${ }^{26}$. In other words, the Church does not fear the freedom of conscience of its believers and people who do not belong to the Church. To the contrary, the Church itself eagerly calls for preserving this freedom and tries to shape it, reprimanding that only those who follow properly-formed conscience ,are humble, submissive, thankful for the help from outside, whereas others react in an arrogant manner in the name of their maturity, rejecting form

${ }^{23}$ Cz. S. Bartnik, Istota chrześcijaństwa, Lublin 2004, p. 253. Cf. Z. Kraszewski, Mariologia w nauce Kościoła, „Powołanie Człowieka” 6 (1983), p. 73; R. Voillaume, Rekolekcje watykańskie, Kraków 1978, p. 32.

${ }^{24}$ Cf. J. Pastuszka, Kapłan - człowiek i duszpasterz, in: A. Hartliński (ed.), Rozważania duszpastersko-katechetyczne, Poznań-Warszawa-Lublin 1967, p. 735.

${ }^{25}$ J. Kodell, Klucz do Pisma Świętego. Katolicki podręcznik do studiowania Pisma Świętego, Kraków 2003, p. 31.

${ }^{26}$ S. Rosik, Sumienie a autorytet, „Studia Theologica Varsaviensia” 1 (1973), p. 183. 
themselves, with indignation, all thoughts about an authority who is instructing them (for instance, the Magisterium)"27.

Furthermore, it is often raised against the Church that it coerces and enforces from its believers obedience hiding behind the explanation that it acts in the spirit of love and truth. What is more, there are many of those who publicly express their joy because of „leaving the Church”. Sharing this joy with others, they think that they are now truly free; that now they are beyond the sphere of bas influence of the clergy and do not have to be held accountable for their actions. Towards such attitudes the Church tries to preserve the principle of universal love, seeking ways leading to the conviction of those, who consider themselves its enemies and forgetting that it is The Holy Spirit who keeps watch over the infallibility of the Church in the matters of faith and traditions ${ }^{28}$.

The awareness of service towards evangelical love and truth put the Church under the obligation to properly use its due God's authority ${ }^{29}$. On many occasions Christ the Lord admonished his disciples saying that those who exercise power in the Church should do so in the spirit of service ${ }^{30}$. Jesus pointed to the necessity

${ }^{27}$ A. Laun, Wspótczesne zagadnienia teologii moralnej. Teologia moralna fundamentalna, Kraków 2002, p. 140.

${ }^{28}$ Cf. F. Grudniok, Kochać kapłaństwo. Rozważania ascetyczno-duszpasterskie na tle przykładu i wypowiedzi Jana Pawła II, Kraków 1984, p. 32. Opinions hostile to the Church bring about chaos on the line: the Magisterium and theology. In the documents of the Church we find numerous important guidelines where the Church hierarchy is called to recognize the right of the believers, clergy and laity concerning their ,freedom of research, thinking and expressing their convictions in the matters where have knowledge humbly and bravely. Accepting the God's revelation from the Church, which is from the awareness of the faith of God's people does not mean, for theology at least, the lack of objective constraint that results from the very structure of the revelation and its prediction by the Church. This is, first of all, constraint by the authority of the Church which is required by the subject itself while applying the proper methodological process. It is important that theology does not break into numerous different explanations or divergent sciences. (...) Theologians should not (...) and cannot take the place of the Magisterium". M. Schmaus, Wiara Kościoła, volume 1: Objawienie - inicjatywa Boża oczekujaca odpowiedzi człowieka: wiary, Gdańsk-Oliwa 1989, p. 342. Cf. R. Rogowski, O postannictwie teologa dzisiaj, Wrocław 1984, p. 181.

${ }^{29}$ „Authority in the Church is a service of love and practice of love. Love is God's power which enables for higher things, and if necessary - „superhuman” ones. Paweł VI, Świadectwo życia chrześcijańskiego, in: E. Weron (ed.), Badźcie mi świadkami. Pawet VI przemawia do ludzi świeckich, Poznań-Warszawa 1975, p. 196.

${ }^{30}$ „Bishops, as vicars and ambassadors of Christ, govern the particular churches entrusted to them by their counsel, exhortations, example, and even by their authority and sacred power, which indeed they use only for the edification of their flock in truth and holiness, remembering that he who is greater should become as the lesser and he who is the chief become as the servant (cf. Luke 22:26-27)". Second Vatican Council, Dogmatic Constitution on the Church Lumen gentium, no. 27. 
of „denying oneself" and openness to others in the spirit of love and truth ${ }^{31}$. He instructed his disciples that defence of love and truth is carried out with the preservation of humbleness and the spirit of service towards all ${ }^{32}$.

The Church, sent to the entire world by its Godly Founder, presents itself as a special extension of the mission which was, in the times of the Old Testament, entrusted with prophets. Indifferent to encountered hardship, the prophets called to repentance not only those who considered themselves sinners but also - and perhaps above all - the so-called just who did not acknowledged their guilt before God. False godliness of the latter was based on a wrong self-assessment. It always happens when a man lacks love and truth.

Hence, the Old Testament prophets admonished not only individuals or some particular community; many of them were often sent by God to the people living in Jerusalem who seemed to obstinately hold on to their sins. The recipients of these admonitions were often times insensitive to the calls for life transformation; they did not want to accept the conditions of repentance and many regarded them severe. Despite this spiritual opposition, the prophets did not cease to remind that God ,always takes mercy when He sees a genuine conviction of the heart and a radical transformation of one's life" 33 .

This truth was proclaimed by, among others, the prophet Jeremiah. He publicly pointed out that Judah is completely saturated with $\sin (\operatorname{Jr} 2: 35-37)$. This sin situation became for the prophet a motivation, , a call for an internal transformation and to begin a dialogue with God (Jr 3:1-5). Is it possible at all for a sinful chosen nation (...) to return to their God? Through the mouth of His prophet the Lord gives an affirmative answer. (...) Thus every Judean should feel called by the Most High to transform, this transformation being based on total commitment to God. Jeremiah proclaims this message with steadfast firmness,

${ }^{31}$ „May that flame which comes from the Holy Spirit reach those of Us who have been raised to the priesthood of Jesus Christ and consume us too. We owe ourselves and all we have to the Church; may we work each day only in her name and by her authority and may we properly carry out the duties committed to us, and may we be joined together in fraternal unity and thus strive to serve her in that perfect way in which she ought to be served". John XXIII, the Encyclical Sacerdoti nostri primordia (1 August 1959).

32 Despite frequent misunderstanding from the contemporary world the Church cannot give up the obligation of full message of the truth of faith and customs being aware that each „incomplete system of values reflects the features of ethical relativism and conditions the phenomena of adjusting actions and motivations to unilateral and subjective assessments, frequently contradictory to common unalterable law of the universal love stimulating for actions which authentically serve the good of a man". W. Fijałkowski, Moralne aspekty pracy ginekologa, położnika i seksuologa, in: K. Osińska (ed.), Refleksje nad etyka lekarska, Warszawa 1990, p. 103.

${ }^{33}$ U. Terrinoni, Słowo Boże i śluby zakonne. Obrazy biblijne - 1. Postuszeństwo, Kraków 2003, p. 81. 
not discouraged by the indifference of the monarchs who were deprived of any religious sensitivity and displayed political short-sightedness" ${ }^{\prime 34}$.

The mission of the Church, whose an integral element is a social teaching and actions for the renewal of culture and society, takes as its model also the attitude of St. John the Baptist. The calling for repentance voiced by the prophet from the Jordan Valley contained a clear postulate of building this life on love and truth. The prophetic activity of John was an exhortation for conversion. The sigh of entering the path of love and truth was baptism accepted in view of approaching Kingdom of God. Shortly before Jesus spoke out, John the Baptist appeared in the Judean Desert. He called for repentance:" and were baptised by him in their Jordan, confessing their sins" (Mt 3:6). Baptism, as a washing in the water which symbolizes the desire for an internal cleansing and transformation of life, was a ritual unknown in the Old Testament. There were numerous ritual washings known which expressed the striving for moral purity; most frequently, though, they were merely a ceremony. St. John baptized demanding a moral conversion ${ }^{35}$.

Those accepting the baptism of John confessed their sins (Cf. Matthew 3:5). St. John required the ones coming to his baptism to bear „fruits worthy of repentance" (Matthew 3:8), namely mercy, honesty, justice. The baptism of penance preached by John was to serve absolution. Although John does not talk clearly about repentance and sorrow ordered by penance, and he does not mention any penitential sacrifices, they are still included in the demand for the transformation of life and turning from evil. The example of John the Baptist himself, leading a penitential life, inclined not only to change internal disposition but also to lead a new life, based on love and truth.

Having its eyes fixed on the example on Saint John the Baptist, the Church above all continues the Apostles' mission in its social involvement. The author of „Acts of the Apostles" marked that God performed more than common miracles by the hand of Paul, among others, ,so that even handkerchiefs or aprons were brought from his body to the sick, and the diseases left them and the evil spirits went out of them" (Act, 19:11-12). The Apostles' eagerness, supported by Christ's gift of miracles, brought extraordinary effects. The trust in them themselves was growing gradually, which is proven by using items of clothing for healing and freeing, as mentioned above, and imitating their method of exorcizing by Jewish

${ }^{34}$ A. Salas, Prorocy - Zwiastuni Boga żywego, Częstochowa 1998, p. 98.

${ }^{35}$ „John the Baptist proclaimed fearful and terrifying God's justice: 'The ax is laid to the root of the trees' (Luke 3:9). God always commiserates when He sees a genuine heart conversion and a radical life change". U. Terrinoni, Stowo Boże i śluby zakonne..., op. cit., p. 81. 
exorcists (Cf. Acts of the Apostles, 19:13-16), as well as numerous conversions which introduced people onto the way to evangelical love and truth.

Just like the Apostles before, over the centuries the Church has been trying to draw away all sinners from evil, evoke compunction, and hold back the attacks of evil spirit. It tries to give help to all, especially to disciples of Christ threatened in their faith, in their earthly ways, draw to penance, by instructing on love and truth. To the ones who are converting, the Church is trying to give assistance in understanding God's mysteries, stimulating them do bigger and bigger eagerness in shaping their surroundings - the environment, the society, the nation - owing to the gifts of love and truth received from $\mathrm{Christ}^{36}$.

\section{Who does the Church Turn to With the Message of Love and Truth?}

The Church calls first of all its faithful to the renewal of culture and the society on the base of love and truth. St Paul writes: „To all who are in Rome, beloved of God, called [to be] saints" (Romans 1:7). The Apostle of the Nations calls all Christians ,the saints”. „To the church of God which is at Corinth, to those who are sanctified in Christ Jesus, called [to be] saints, with all who in every place call on the name of Jesus Christ our Lord” (1 Corinthians 1:1). Membership of „the saints" cannot be purely external, but it obliges to the transformation of personal and communal life, to internal sanctification, the fruit of which are „love, joy, peace, longsuffering, kindness, goodness, faithfulness, gentleness, self-control" (Galatians 5:22 -23).

Setting such requirements to all ,who are sanctified in Christ Jesus, called [to be] saints, with all who in every place call on the name of Jesus Christ our Lord" (1 Corinthians 1:1) assumes that holiness is a duty of all Christians, and not special charisma that only some chosen ones are entitled to. Thus, the restoration of culture and society which are co-created by the disciples of Christ, demands „a testimony about this liveliness of faith brought about by the Holy Spirit. The testimony of the living God, still close to the man, and the testimony about the man who experiences this miraculous transformation of life owing to this closeness" ${ }^{\prime 7}$.

${ }^{36}$ „The Apostles accurately fulfill the orders received from Christ. Since Pentecost, they have called to conversion by preaching the Gospel". Z. Adamek, Homiletyka, Tarnów 1992, p. 111.

${ }^{37} \mathrm{~K}$. Jeżyna, Jedność wiary i życia moralnego w perspektywie nowej ewangelizacji, „Roczniki Teologiczne" 3 (2001), p. 104. 
The wish to submit totally to the Holy Spirit in order to get rid of the „earthly, carnal" attitude and way of thinking should be the crucial motive. Thus, it is about the basic requirement of Christian life. The Church does not expect any external symbols from its faithful but ,the internal transformation of the heart under the influence of the word of God, the signs of time or another way of acting of the Holy Spirit (see: Matthew 4:17, Mark 1:15); (...) permanent conversion, that is a definite effort of the man to turn into 'a new man"' (Cf. Ephesians 4:23-24) or even to be becoming perfect in imitation of Father in heaven who is perfect" ${ }^{\prime 38}$.

The Church teaches that the consequence of meeting Jesus should be a radical departure from hatred and lie within the framework of culture and social life for the benefit of love and truth ${ }^{39}$. It is about ,the transformation of the whole attitude of life. One must leave the previous way of thinking and valuating, one must look at people in the way suggested by the Gospel. Only the one who has believed in Christ is able to such a transformation of life. Therefore, in addition to conversion, the basic goal of prophesying is faith which (...) „,comes by hearing, and hearing by the word of God" (Romans 10:17). Thus, the aim of prophesying is not only to awaken faith but also to deepen and strengthen it, which leads to carrying the heard and accepted word into effect" ${ }^{40}$.

Children and the youth constitute a special area of care in the social involvement of the Church. It tries to form the faithful spiritually from the earliest childhood. Christian tutors should be a point of support for their pupils on their way to the renewed culture of the new society. Meeting with the living Christ who does not violate human freedom in any way but is the point of support and the very sense and source of love and truth in human life is rightly assumed to be one of the major tasks of catechesis, for example.

The time of childhood and youthful growing up is the awakening awareness of passing of life and time. Just like in the whole evangelization, bringing about the internal transformation of all pupils is in the centre of catechization: „The word of

${ }^{38}$ J. Michalik, Kościół przepowiadający i czyniący pokutę, in: A.J. Nowak, W. Słomka (ed.), Mitość większa niż grzech, Lublin 1996, p. 22.

${ }^{39}$ Cf. P. Nitecki, Katechizm i jego miejsce w nauczaniu Kościoła, „Collectanea Theologica” 2 (1995), p. 13.

${ }^{40}$ Z. Adamek, Homiletyka..., op. cit., p. 111. „When evangelizing, the Church shapes human conscience and prepares hearts to accept God in the inspired word and holy sacraments". E. Mitek, Metody i środki ewangelizacji rodzin poprzez wychowanie dzieci i młodzieży, „Katecheta” 1 (1981), p. 22. 
God heard at the catechesis leads to constant conversion and the transformation of life through which also its main goal is realized"41.

Religious upbringing, especially in this basic „social cell” which is a family, should lead to the transformation of life and, if necessary, to breaking up with the hitherto prevailing way of conduct ${ }^{42}$. What comes from the sacrament of matrimony is ,,a spiritual house, a holy priesthood, to offer up spiritual sacrifices". (1 Peter 2:5). Baptism is the primal source of the sanctification of family. It finds the fullest expression in the Eucharist, with which it is primarily connected. The Eucharist is a source of marriage and family since being the sacrament of Christ sacrifice, at the same time it is the sacrament of love and union in the Body of Christ. (...) Common priesthood of the faithful experienced in the sacrament of matrimony is the base for establishing a family, family life changes into a „spiritual” sacrifice which is nice to God by Jesus Christ in the Holy Spirit”"

The Church involvement in the work on the renewal of culture and society on the foundation of love and truth includes also the ones who are outside its visible structure since prophesying the Good News about the True Triune God, Father of everyone and the whole human family, is an integral element of the Church mission. The common scope of the Church mission, as defined in such a way, appears most of all to be the sign of the service to the man and the whole mankind. It is a message which may really constitute and it does constitute one of significant premises of hope for the humanization of the world and human life, the hope for so-called human world. Wherever the prophesied Gospel found people who believed in it, it joined the faithful into communities, deeply transformed their life, showed to the eyes of the amazed pagans that life in love and truth is possible - even until the martyr's death (see: Philippians 2:14 -15, 1 Peter 3:16).

The common mission was entrusted to the Church by Jesus. He himself was able to lead to a radical change of life of many people, his disciples ${ }^{44}$. God's logics differs from the human way of thinking. Human wisdom does not constitute the measure of the man's value for God. The Christian wisdom is not a school of philosophy but an existential value, it embraces the whole man. The Cross is its centre. It is not, like human wisdom, the wisdom of the word, that is it, does not

${ }^{41}$ S. Łabendowicz, Katecheza w stużbie ewangelizacji, „Roczniki Teologiczno-Kanoniczne” 6 (1989), p. 137.

${ }^{42}$ Cf. M.I. Drozd, Miłosierdzie jako rys postawy ,chrześcijańskiej wedtug Gwidona z Montpellier i Konstytucji Zakonu Ducha Świętego de Saxia, in: W. Słomka (ed.), Miłosierdzie w postawie ludzkiej, Lublin 1989, p. 149.

${ }^{43}$ G. Lewandowski, Odpowiedzialność rodziców za ksztaltowanie osoby dziecka $w$ świetle wybranych dokumentów Jana Pawła II, „Studia Pelplińskie” 33 (2003), p. 416.

${ }^{44}$ Cf. A. Pronzato, Chleb na niedzielę, Komentarz do Ewangelii-Rok C, Kraków 2003, p. 135. 
depend on sophistry and form, which could deprive the Cross of Christ of the content. Therefore, the Church mission is and must remain common, it will fulfill everywhere where the preached word of God meets listeners, ready to give the answer of faith, which will transform their personal and social life according to the evangelical values of love and truth.

It is worth adding here that the technological progress is not in the centre of the attention of the Church involved in the renewal of culture and society. If the Church expresses its opinion it does so in the situations in which technical progress and development is perceived as a cause or a result of various kinds of transformation of individual or social life. The interest of the Church instruction is carried from the analysis of goods produced in this area to the man who is the major creator and the goal of these processes. The critical voice of the Church concerns the method of using the technical progress and development; it hopes that people who do not belong to the Church convert to Jesus wholeheartedly and will accept His instruction which obliges to shaping the whole life - also in the area of the technical progress and development - in accordance with the evangelical love and truth ${ }^{45}$.

\section{The Final Goal of the Social Mission of the Church: the Kingdom of God}

Numerous philosophical trends seek the measure of all things in the man. Indeed, consciousness and self-consciousness give the man a unique place in the whole created world; he knows that he is a man, he is able to define his relations to himself and the relations of the world to him. „He measures himself and virtually measures the whole created existence" ${ }^{\prime 46}$. However, in the statement that the man constitutes the measure of everything we cannot overlook the fact that also he himself is created. He is not a creator, he is not a king, but the explorer and the commentator of the world ${ }^{47}$. On the other hand, God is the King; His measure is „absolute, exclusive, and totally original”48.

The man, as a created creature, possesses the nature which is adequate for him - the essence. It characterizes with the fact that it is ,in the state of becoming,

${ }^{45}$ Cf. K. Bukowski, Religie świata wobec chrześcijaństwa, Kraków 1999, p. 361.

${ }^{46}$ A. Leonard, Bóg pozwolit nam zasiasść w niebie w Chrystusie Jezusie, „Communio” 8 (1987), p. 114.

${ }^{47}$ Cf.: Ibidem.

${ }^{48}$ Ibidem, p. 115. 
namely history"49. But the sin has deformed human relations: of the man with himself, with the world, but most of all with God. Yet, on the strength of the redemption of Jesus ,your life is hidden with Christ in God" (Colossians 3:3). Our life is hidden in God because the love of God allows to develop to the measure „that God gives us in his creative cognition, penetrating us up to the smallest fibres and embracing our beginning and end into one unity" 50 . What is more, our life is hidden in God with Christ.

The fact of Incarnation was the cause for which the measure of our humanity is not above us but ,the divine measure of our humanity has become a particular Man in our history" ${ }^{\circ 1}$. The content and the limit of shaping human existence „reconciled with himself, with others, with God" ${ }^{52}$, revealed in Christ - GodMan. The man was planted into Christ who after His resurrection sits at the right hand of God. Therefore, the man is not a king; he is not the measure of everything. Only personal entering into the relations with Resurrected Jesus constitutes a hope for the man for the full realization of the potential inherent to his nature. Owing to Christ, the man is striving at perfection which he will achieve in the eschatological fullness.

Not only a single man but also the whole human community should strive at this fullness via evangelical love and truth. Therefore, the final end, to which the Church involvement in the renewal of culture and society leads, is inseparably connected not with the worldliness but with the eschatological fullness of the Kingdom of God. The Apocalypse of John is a special source of discovering this fullness. „Now I saw a new heaven and a new earth, for the first heaven and the first earth had passed away. Also there was no more sea" (Revelation 21:1). In comparison with the words from the Book of Genesis: „In the beginning God created the heavens and the earth” (1:1) and the Book of Isaiah: „For behold, I create new heavens and a new earth" (65:17), the words of the Apocalypse indicate that in the final times a new reality will appear. The present world will undergo transformation and improvement and ,the old and imperfect kingdom will pass, and in its place a new nation will emerge whose the only Master and King will be God himself"53.

\footnotetext{
${ }^{49}$ Ibidem.

${ }^{50}$ Ibidem, p. 117.

${ }^{51}$ Ibidem.

${ }^{52}$ Ibidem.

${ }^{53}$ F. Mickiewicz, Wizja nowego nieba i nowej ziemi w Ap 21,1 - 22,5, „Communio” 4 (2000),
} p. 23. 
The emergence of the new reality will be a consequence of the intervention of God himself: „Behold, I make all things new” (Revelation, 21:5). This thought is already included in the Old Testament which indicates God - Yahweh as the King, Master, Ruler of the whole world. In the Old Testament we can see deep faith that Yahweh will accomplish a transformation of the man and the humanity. It will happen in eschatological times, which are defined by prophets and apocalyptic writers as ,great Sabbath in which God will triumph in the world and after judging the living and the dead (...) he will begin a new era on the earth and in heaven" 54 .

On the foundation of the old testament revelation, the New Testament bounds the future of the world to the triumph of the promised Messiah - Jesus Christ. Alongside His coming into the world ,a new covenant” (Matthew 26:28), ,, a new commandment” (John 13:34) and „newness of life” (Romans 6:4) materialized. Thanks to the grace of redemption, the man becomes ,a new man”, „one new man” (Ephesians 2:15), receives „a new name”. All these expressions show the materialization of the transformation of the man, as well as of the humanity ${ }^{55}$.

The Kingdom of God will irradiate with the glory of God and the Lamb. It will be a fulfillment of the promise of New Jerusalem. There is a throne in its centre. Christ himself sits on it together with Father. He, as the Conqueror thanks to paschal offering, made the judgement over the world, destroying all the evil. Heavenly Jerusalem is a symbol of a new harmonious world of all the saved (symbolically it is expressed in the perfect shapes and the splendor of the heavenly Jerusalem). Chris as a Conqueror gives a share in His life to all the community of the saved: „To him who overcomes I will grant to sit with Me on My throne" (Revelation 3:21) ${ }^{56}$.

The connection between the individual happiness of a man and the happiness of other saved in Christ is expressed by the reality of the Kingdom of God as the Kingdom of Christ. These two phrases do not define two separate realities - it is one reality. Redemption made by God is defined already in the Old Testament as the reign of His kingdom. He promised to established His kingdom through Messiah. It was Jesus Christ who appeared to be this intermediary. From the very beginning His activity concerned prophesying the Kingdom of God embracing the whole human race: „In the life and passion of Jesus, God's redemptive plans materialized. The one who preached the Kingdom (of God) now is becoming the one in whom the Kingdom is beginning to exist in full and is becoming

\footnotetext{
${ }^{54}$ F. Mickiewicz, Królestwo Chrystusa - wieczne i powszechne, „Communio” 2 (1997), p. 50.

${ }^{55}$ F. Mickiewicz, Wizja nowego nieba..., op. cit., p. 24.

${ }^{56}$ Cf. Ibidem, p. 27.
} 
the Kingdom of Christ"'57. Being with Christ means the fullness of life for the community of the saved because, as ST Augustine says, „where Christ is, there is life, there is the kingdom" 58 .

Thus, the idea of a temple plays a very important role in understanding the essence of the Kingdom of God as a community of the saved in Christ. In the Old Testament it was a place in which the glory of God stayed; it was a place of meeting between God and the man. According to St John's vision, the community of the saved in heavenly Jerusalem does not need any intermediation anymore because "not only the whole heavenly Jerusalem is a temple, but also the saints live in God and the Lamb, just like God and the Lamb live in the saints"59.

\section{Final reflection}

At present, frequently hearing about the crisis of the Church involvement in the renewal of culture and society, one should always remember not to mix this crisis up with ,the sign of objection" that the Church is and should be. It is a historical fact that even the first disciples of Christ were the sign of objection. Risen from the dead ,he appears only to a few witnesses who have no authority among people and are almost disgraced just for their friendship with Jesus. And those witnesses, the only and the last ones (together with Saint Paul) in the whole history of the Church cannot say anything else than „We saw, we witness, we believe"60.

Similarly, the Church is the sign of objection in the contemporary world. Preaching ,the truth in love" and „love in the truth" to the world requires „courage and humility" ${ }^{\prime \prime 1}$. The way to recover the authority where the Church would lose it is always the return to the ideal in Jesus Christ. What is more, every crisis in the dialogue with the world may be for the Church a call to even more firm return to the way of evangelical love and truth ${ }^{62}$. Taught by the experiences from the

${ }^{57}$ Fi. Mickiewicz, Królestwo Chrystusa.., op. cit., p. 53.

${ }^{58}$ Ibidem, p. 62.

${ }^{59}$ F. Mickiewicz, Wizja nowego nieba..., op. cit., p. 32.

${ }^{60}$ G. Huyghe, Ukrzyżowany również za nas pod Poncjuszem Piłatem został umęczony i pogrzebany. I zmartwychwstat trzeciego dnia, jak oznajmia Pismo. I wstapit do nieba, siedzi po prawicy Ojca, in: VV. AA., Wiara Kościoła. Biskupi francuscy komentuja Wyznanie Wiary, Warszawa 1985, p. 237.

${ }^{61}$ T. Radcliffe, Dla radości, która Mu obiecywano - nauka Kościoła a codzienne życie, „W drodze" 6 (2003), p. 68.

${ }^{62}$ One of the theologians expresses it in the following way: „For many years in Ireland the Church enjoyed great respect, it was at the top of the society. Now it has fallen - from the height. 
past, the Church is aware that what is necessary for the renewal of culture and society, is evangelical love and truth, since although ,we are rightly concerned with the complex and serious character of the present economic situation, still, with realism, trust and hope we should accept new responsibility to which we are called by the scenario of the world which needs deep cultural renewal and to discover fundamental values on which we can build a better future"63.

\section{Bibliography}

Adamek Z., Homiletyka, Tarnów 1992.

Bartnik Cz. S., Istota chrześcijaństwa, Lublin 2004.

Bukowski K., Religie świata wobec chrześcijaństwa, Kraków 1999.

Congar Y., Wierzę w Ducha Świętego, volume 1, Warszawa 1997.

Fros H., Pamiętając o mieszkańcach nieba. Kult świętych $w$ dziejach $i$ w liturgii, Tarnów 1994.

Guardini R., O Bogu żywym, Warszawa 1987.

Hryniewicz W., Dlaczego głoszę nadzieję?, Warszawa 2004.

John Paul II, Misja nauczania Nastęcy św. Piotra, in: John Paul II, Wierzę w Kościót jeden, święty, powszechny i apostolski, Libreria Editrice Vaticana 1996, p. 248-253.

Kodell J., Klucz do Pisma Świętego. Katolicki podręcznik do studiowania Pisma Świętego, Kraków 2003.

Kopeć E., Teologia fundamentalna, Lublin 1976.

Kowalczyk S., Liberalizm i jego filozofia, Katowice 1995.

Kumor B., Historia Kościoła, volume 4, Jesień kościelnego średniowiecza, Lublin 2001.

Laun A., Współczesne zagadnienia teologii moralnej. Teologia moralna fundamentalna, Kraków 2002.

Paweł VI, Świadectwo życia chrześcijańskiego, in: Weron E. (ed.), Badźcie mi świadkami. Pawet VI przemawia do ludzi świeckich, Poznań-Warszawa 1975, p. 196.

Pronzato A., Chleb na niedziele, Komentarz do Ewangelii-Rok C, Kraków 2003.

Rahner R., Wierzę w Jezusa Chrystusa, Paris 1977.

The fall is painful and humiliating. But these are the consequences of complacency! Probably through the present crisis God teaches us humility. A A painful lesson, but really necessary! Only when the last unhealthy pride disappears, the Irish clergy will be able to recognize what the Holy Spirit wants to do in the present situation. By the way, I want to add one minor remark: unhealthy pride and somniferous complacency are not the exclusive ownership of the Irish! They may also exist in other Churches!". D. Sullivan, Refleksje na temat kryzysu w Kościele irlandzkim, „Przegląd Powszechny” 5 (2003), p. 273.

${ }^{63}$ Benedict XVI, Encyclic Caritas in veritate (29 June 2009), No. 21. 
28 Volume 2 (2012) Number 2

Salas A., Prorocy - Zwiastuni Boga żywego, Częstochowa 1998.

Tatarkiewicz W., Historia filozofii, volume 1, Warszawa 1993.

Terrinoni U., Słowo Boże i śluby zakonne. Obrazy biblijne - 1. Postuszeństwo, Kraków 2003.

Voillaume R., Rekolekcje watykańskie, Kraków 1978. 